\title{
HUBUNGAN USIA DAN MASA KERJA DENGAN NILAI AMBANG DENGAR PEKERJA YANG TERPAPAR BISING DI PT. X SIDOARJO
}

\author{
Winda Wahyuni Putri, Tri Martiana \\ Departemen Keselamatan dan Kesehatan Kerja, \\ Fakultas Kesehatan Masyarakat Universitas Airlangga \\ E-mail: windawahyuniputry@gmail.com
}

\begin{abstract}
One factor that could result in disturbance of health in the process production is noise the following noise interferes due to the use of thr machine production. The purpose of this study was to analyze the correlation of age and working period with hearing threshold value of workers exposed to noise in the unit of production Steel Melting Shop PT. X Sidoarjo. This study used cross-sectional design. Population of the study is labor in the production of Steel Melting Shop PT. X Sidoarjo as many as 108 employees. Samplesin this study are 28 employees, taken by simple random sampling with criteria inklusi willing to be the sample of the research and not experience pain (no history of ear disease and had never experienced head trauma). Variables independent is age, and working period. Variable dependent is a hearing threshold value. Noise measurements in the unit production of Steel Melting Shop PT. X Sidoarjo show his worth beyond NAB (106 dB s/d 107 $d B)$. Workup audiometri show 22 from 28 sample had abnormal hearing threshold value ( $>25 \mathrm{~dB})$. Test with correlation pearson showed relationship age and working period with hearing threshold value. Conclusion from this study is that noise in the unit production of Steel Melting Shop PT. X Sidoarjo beyond NAB and many workers had abnormal hearing threshold value as the correlation of age and working period with a worker hearing threshold value PT. X Sidoarjo. Do the rotation of workers to reduce long exposure to high risk workers exposed to noise.
\end{abstract}

Keywords: age and working period, hearing threshold value, noise exposure

\begin{abstract}
ABSTRAK
Salah satu faktor yang dapat mengakibatkan gangguan kesehatan dalam proses produksi adalah kebisingan berupa suara yang mengganggu akibat penggunaan mesin produksi. Tujuan penelitian untuk menganalisis hubungan usia dan masa kerja dengan Nilai Ambang Dengar pekerja yang terpapar bising di unit produksi Steel Melting Shop PT. X Sidoarjo. Penelitian ini menggunakan rancangan cross-sectional. Populasi dalam penelitian ini adalah tenaga kerja di unit produksi Steel Melting Shop PT. X Sidoarjo sebanyak 108 pekerja. Sampel penelitian sebanyak 28 pekerja yang diambil secara simple random sampling dengan kriteria inklusi bersedia menjadi sampel penelitian dan tidak mengalami sakit (tidak memiliki riwayat penyakit telinga dan tidak pernah mengalami trauma kepala). Variabel independen adalah usia dan masa kerja. Variabel dependen adalah nilai ambang dengar. Pengukuran kebisingan di unit produksi Steel Melting Shop PT. X Sidoarjo, menunjukkan nilainya melebihi NAB (106 dB s/d 107 dB). Hasil pemeriksaan audiometri menunjukkan 22 dari 28 sampel nilai ambang dengarnya tidak normal ( $>25 \mathrm{~dB})$. Pengujian dengan uji korelasi pearson menunjukkan ada hubungan usia dan masa kerja dengan nilai ambang dengar pekerja. Kesimpulan penelitian ini adalah kebisingan di unit produksi Steel Melting Shop PT. X Sidoarjo, melebihi NAB dan banyak pekerja memiliki Nilai Ambang Dengar tidak normal serta ada hubungan usia dan masa kerja dengan Nilai Ambang Dengar pekerja PT. X Sidoarjo. Lakukan rotasi pekerja untuk mengurangi lama paparan pada pekerja yang berisiko tinggi terpapar bising.
\end{abstract}

Kata kunci: usia dan masa kerja, Nilai Ambang Dengar, terpapar bising

\section{PENDAHULUAN}

PT.X Sidoarjo merupakan perusahaan yang bergerak di bidang manufacturing yaitu perusahaan peleburan baja, yang terletak di Desa Kedungturi, Taman, Sidoarjo. Bahan baku utama yang diolah dalam peleburan pabrik ini adalah steel scrap (besi tua) dan sponge iron. Bahan baku tambahannya adalah berupa ferro silicon, ferromanganese, ankerfrit $n x$ 95, ankerhearth nn 95, dolomite, lime, carbon raiser 211, dan bahan penolong lainnya yang akan diolah menjadi billet (balok baja dengan ukuran tertentu) dan wire rod. PT. X Sidoarjo salah satu industri terbesar yang memproduksi baja.

Steel melting shop merupakan tempat peleburan besi-besi tua sedangkan Steel making merupakan proses peleburan besi-besi tua (scrap). Proses 
peleburan ini menggunakan alat EAF (Elektrik Arc Furnace), setelah proses peleburan dilakukan proses yang menggunakan alat bernama $L R F$ (Ladle Refining Furnace) dan proses selanjutnya cairan baja yang telah ditentukan komposisinya kemudian dicetak menggunakan CCM (Countinous Casting Machine) menjadi billet (baja balok dengan kekebalan dan panjang tertentu) yang menimbulkan suara bising yang diakibatkan oleh benturan besi atau baja pada saat proses peleburan pada mesin EAF dan alat-alat ini memiliki nilai intensitas kebisingan melebihi Nilai Ambang Batas (NAB).

Pengoperasian mesin di Steel Melting Shop PT.X Sidoarjo dilakukan selama 1 shift kerja yaitu 7 jam sampai dengan 8 jam sehari. Pengoperasian mesin-mesin tersebut sangat mungkin menimbulkan kebisingan yang mengakibatkan gangguan pendengaran pada pekerja dikarenakan kebisingan yang ditimbulkan adalah bising yang berkelanjutan (continued noise).

Operasional pabrik PT. X Sidoarjo khususnya di unit produksi Steel Melting Shop yang menggunakan peralatan mesin yang dalam kegiatan produksi semuanya menimbulkan kebisingan. Kebisingan berpotensi mempengaruhi kenyamanan dan kesehatan operator yang bekerja di dalam lingkungan pabrik. Gangguan yang tidak dicegah maupun diatasi bisa menimbulkan kecelakaan, baik pada pekerja maupun orang di sekitarnya. Kondisi inilah yang membuat pekerja di unit produksi terpapar oleh bising selama jam kerja. Bising yang timbul akibat mesin produksi sering dikeluhkan oleh para pekerja di area tersebut.

Kebisingan atau Noise pollution sering disebut sebagai suara atau bunyi yang tidak dikehendaki atau dapat diartikan pula sebagai suara yang salah pada tempat dan waktu yang salah (Chandra, 2007) sedangkan menurut Soemirat (2011), mengatakan bahwa bising adalah campuran dari berbagai suara yang tidak dikehendaki ataupun yang merusak kesehatan.

Salah satu faktor yang dapat mengakibatkan gangguan kesehatan dalam proses produksi adalah kebisingan yang berupa suara yang mengganggu yang dihasilkan akibat penggunaan mesin produksi. Menurut Suma'mur (2009), Bunyi atau suara didengar sebagai rangsangan pada sel saraf pendengar dalam telinga oleh gelombang longitudinal yang ditimbulkan getaran sumber bunyi atau suara dan gelombang tersebut merambat melalui media udara atau penghantar lainnya, dan apabila bunyi tersebut tidak dikehendaki oleh karena mengganggu atau timbul di luar kemauan orang yang bersangkutan, maka bunyi-bunyian demikian dinyatakan sebagai kebisingan.

Karyawan industri sangat rentan terhadap kerusakan pendengaran dalam bentuk pergeseran ambang dengar temporal TTS (temporary threshold shift) diakibatkan pemaparan terhadap bising dengan intensitas tinggi. Seseorang akan mengalami penurunan daya dengar yang sifatnya sementara dan biasanya waktu pemaparan terlalu singkat. Apabila tenaga kerja diberikan waktu istirahat secara cukup, daya pendengaran seseorang akan pulih kembali (Prabu, 2009).

Sesuai dengan data pengukuran tingkat kebisingan yang di dapat dari perusahaan di bagian produksi, rerata intensitas kebisingan di luar control room LRF (Laddle Refining Furnace) sebesar $103 \mathrm{~dB}$, depan control room EAF (Electrical Arc Furnace) sebesar $106 \mathrm{~dB}$ dan di depan control room CCM (Countinous Casting Machine) sebesar 104 $\mathrm{dB}$ sedangkan tenaga kerja harus bekerja selama 7 sampai 8 jam sehari.

Suasana yang bising memaksa pekerja untuk berteriak di dalam berkomunikasi dengan pekerja lain. Kadang-kadang teriakan atau pembicaraan yang keras ini dapat menimbulkan salah komunikasi (miscommunication) atau salah persepsi terhadap orang lain. Lebih jauh, kebisingan terus menerus dapat mengakibatkan gangguan konsentrasi pekerja yang akibatnya pekerja cenderung berbuat kesalahan dan akhirnya menurunkan produktivitas kerja (Notoatmodjo, 2007).

Penelitian Siregar (2010), pada tenaga kerja kelapa sawit diperoleh data 22 tenaga kerja mengalami tuli ringan dan pada telinga kanan 10 tenaga kerja pada telinga kiri.

Data dari ILO (Internasional Labour Organisation) tahun 2012 hampir 2,3 juta orang meninggal setiap tahun di seluruh dunia akibat kecelakaan kerja dengan kerugian mencapai 4 triliun US \$. Data dari International Labour Organization (ILO) menghasilkan kesimpulan, setiap rata-rata 6000 orang meninggal, setara dengan satu orang setiap detik, atau 2,2 juta per tahun akibat sakit atau kecelakaan kerja yang berkaitan dengan tenaga kerjaan mereka.

Data dari Kementerian Tenaga Kerja dan Transmigrasi (Kemenakertrans, 2010) menyebutkan sepanjang tahun 2009 telah terjadi 54.398 kasus kecelakaan kerja di Indonesia. Maka dapat di asumsikan bahwa ada 17 tenaga kerja yang mengalami cacat fungsi akibat kecelakaan kerja 
setiap hari dan salah satu faktor utama penyebabnya adalah kondisi lingkungan kerja yang tidak aman.

Berdasarkan Peraturan Menteri Tenaga Kerja dan Transmigrasi Nomor: 13 Tahun 2011, Tentang Nilai Ambang Batas (NAB) Faktor Fisika dan Kimia di Tempat Kerja pasal 5 ayat 1 yang menyebutkan bahwa "NAB kebisingan ditetapkan sebesar 85 decibel A (dBA)". Nilai ambang batas kebisingan di tempat kerja adalah intensitas tertinggi dan merupakan nilai rata-rata yang masih dapat diterima tenaga kerja tanpa mengakibatkan hilangnya daya dengar yang tetap untuk waktu kerja secara terus menerus tidak lebih dari 8 jam sehari dan 40 jam seminggu.

Tujuan penelitian adalah melihat apakah kenaikan nilai ambang dengar pada pekerja yang terpapar bising disebabkan oleh pengaruh faktor karakteristik pekerja seperti usia dan masa kerja. Penelitian ini dilakukan pada pekerja yang terpapar bising di tempat kerja (kebisingan lebih dari NAB). Pekerja yang terpapar bising diperoleh dari unit produksi Steel Melting Shop PT. X Sidoarjo.

\section{METODE}

Jenis penelitian ini adalah penelitian analitik karena ingin melihat hubungan usia dan masa kerja dengan nilai ambang dengar pekerja yang terpapar bising. Menurut cara pengambilan data penelitian ini termasuk penelitian observasional karena penelitian dilakukan dengan melakukan pengamatan terhadap objek penelitian. Penelitian ini bersifat Cross-sectional jika dilihat dari segi waktu karena pengumpulan dan pengambilan data dilakukan pada satu kurun waktu yang sama (Notoatmodjo, 2010).

Penelitian ini dilaksanakan di unit produksi Steel Melting Shop PT. X Sidoarjo selama 3 bulan yaitu bulan Agustus sampai bulan Oktober 2015 yaitu untuk pengambilan data dan pengolahan data. Populasi dalam penelitian ini adalah pekerja yang terpapar bising yaitu semua pekerja yang bekerja di unit produksi Steel Melting Shop PT. X Sidoarjo yang berjumlah sebanyak 108 pekerja.

Dalam penelitian ini dilakukan pengambilan sampel dengan teknik simple random sampling didapatkan hasil perhitungannya yaitu dengan jumlah sampel 85 orang, kemudian yang menjadi responden dalam penelitian ini adalah berjumlah 28 orang pekerja yang terpapar bising setelah diambil acak berdasarkan kriteria inklusi.

Kriteria inklusi pada penelitian ini yaitu lama bekerja minimal 5 tahun, bekerja di bagian unit produksi dan officer, pekerja yang bersedia menjadi responden untuk diteliti dengan menandatangani surat persetujuan, tidak dalam keadaan sakit (tidak memiliki riwayat penyakit telinga dan tidak pernah mengalami trauma kepala) dan berumur tidak lebih dari 40 tahun, tidak mengonsumsi obat-obatan ototoksik, serta riwayat pekerjaan sebelumnya tidak terpapar bising. Instrumen penelitian yang digunakan yaitu sound level meter untuk mengukur kebisingan lingkungan, kuesioner serta lembar observasi.

Untuk pengukuran kebisingan di unit produksi Steel Melting Shop menggunakan alat ukur yaitu sound level meter, diukur pada tiga area masingmasing dua titik pengukuran yaitu pada area depan control room dan dalam control room EAF (Electrical Arc Furnace), pada area depan control room dan dalam control room LRF (Laddle Refining Furnace) dan pada area depan control room dan dalam control room CCM (Countinous Casting Machine).

Variabel independen dalam penelitian ini adalah usia dan masa kerja dan untuk variabel dependen adalah Nilai Ambang Dengar pekerja. Data primer diperoleh dari pengukuran intensitas kebisingan dan observasi serta wawancara langsung dan memberikan beberapa pertanyaan melalui lembar kuesioner kepada responden, sedangkan data sekunder yaitu data pengukuran test audiometri serta profil perusahaan yang diperoleh dari PT. X Sidoarjo. Data penelitian yang diperoleh yaitu hasil pengukuran, kuesioner, wawancara maupun observasi dianalisis dengan uji korelasi pearson untuk mengetahui kuat hubungan karakteristik pekerja (usia dan masa kerja) dengan Nilai Ambang Dengar pekerja yang terpapar bising dengan menggunakan $\alpha=0,05$ dan tabulasi silang untuk distribusi data.

\section{HASIL}

\section{Proses Produksi Steel Melting Shop PT. X Sidoarjo}

Steel making merupakan proses peleburan besibesi tua (scrap). Scrap ini diperoleh sebagian besar secara impor dan sebagian local yang selanjutnya ditaruh di area Logistic untuk dipilah-pilah. Scrap yang berasal dari tabung gas, bekas APAR dan lain-lain yang ada kemungkinan meledak tidak dimasukkan untuk ikut diproses. Kemudian scrap yang telah dipilah untuk selanjutnya diangkut oleh dump truck di bawa ke area SMS (Shop Melting Steel) untuk dileburkan. 
Scrap tersebut dipindah dari dump truck ke bucket yang selanjutnya diangkat oleh crane dimasukkan ke dalam Ladle untuk dileburkan. Proses peleburan ini menggunakan alat $E A F$ (Electrical Arc Furnace) berupa 3 elektroda bertenaga listrik dengan kekuatan 80 MVA. Agar meleleh dibutuhkan pemanasan selama hampir 1 jam, yakni 55 menit dengan suhu sekitar $1600^{\circ} \mathrm{C}$. Dalam proses ini bertujuan untuk memisahkan antara baja dengan limbah/residu bernama slag. Setelah proses peleburan dilakukan proses pemurnian untuk mengatur komposisi cairan baja agar memperoleh kualitas yang diharapkan. Prosesnya menggunakan alat yang bernama LRF (Ladle Refining Furnace) dengan suhu sekitar $1600^{\circ} \mathrm{C}$ dibutuhkan waktu selama 1 jam untuk proses pemurnian ini. Proses selanjutnya cairan baja yang telah ditentukan komposisinya kemudian di cetak menggunakan CCM (Continous Casting Machine) menjadi billet (baja balok dengan ketebalan dan panjang tertentu) dan dibutuhkan waktu selama hampir 1 jam untuk proses pencetakan menjadi billet.

\section{Hasil Pengukuran Kebisingan di Unit Produksi Steel Melting Shop}

Area produksi SMS (Steel Melting Shop) terdiri dari beberapa alat untuk peleburan besibesi tua yaitu EAF (Electrical Arc Furnace) untuk proses pemurnian setelah dilakukan peleburan menggunakan alat yang disebut LRF (Laddle Refining Furnace), dan untuk selanjutnya dilakukan pencetakan balok baja yang biasa disebut billet dengan menggunakan alat CCM (Countinous Casting Machine). Letak dari ketiga alat produksi tersebut berada di dalam sebuah bangunan semi terbuka dan didalamnya juga terdapat ruang operator setiap satu alat terebut. Dengan kondisi bangunan semi terbuka seperti ini, kebisingan yang dihasilkan oleh mesin-mesin secara langsung mengenai para pekerja kecuali pekerja di bagian operator yang kedap suara. Ruang operator merupakan ruang terpisah dari area EAF (Electrical Arc Furnace), LRF (Laddle Refining Furnace) dan CCM (Countinous Casting Machine) namun masih dalam satu area Steel Melting Shop. Ruangan tersebut berisi alatalat pengatur mesin untuk peleburan, pemurnian dan pencetakan baja yang terpusat dan termonitor dengan baik. Di ruangan operator EAF (Electrical Arc Furnace) intensitas kebisingan sebesar 73 dBA. Jika dibandingkan dengan luar ruangan operator
EAF (Electrical Arc Furnace) merupakan area kerja terbising dalam satu area Steel Melting Shop.

Berdasarkan pengukuran intensitas kebisingan yang dilakukan didapatkan hasil intensitas kebisingan pada area depan control room $E A F$ (Electrical Arc Furnace) sebesar 106-107 dBA (terpapar) dan memiliki rerata kebisingan sebesar 106 dBA. Pada area dalam control room $E A F$ (Electrical Arc Furnace) didapatkan hasil intensitas kebisingan sebesar 73-75 dBA (tidak terpapar) dan memiliki rata-rata kebisingan sebesar $73 \mathrm{dBA}$. Pada area depan control room LRF (Laddle Refining Furnace) didapatkan hasil intensitas kebisingan sebesar 103-105 dBA (terpapar) dan memiliki rerata kebisingan sebesar 103 dBA sedangkan pada area dalam control room LRF (Laddle Refining Furnace) didapatkan hasil intensitas kebisingan sebesar 83-84 dBA (tidak terpapar) dan memiliki rerata $83 \mathrm{dBA}$. Pada area depan control room CCM (Countinous Casting Machine) didapatkan hasil intensitas kebisingan sebesar 104-107 dBA (terpapar) dan memiliki rerata kebisingan sebesar 104 dBA sedangkan pada area dalam control room CCM (Countinous Casting Machine) didapatkan hasil intensitas kebisingan sebesar 83-84 dBA (tidak terpapar) dan memiliki rerata $83 \mathrm{dBA}$.

Jenis kebisingan yang terjadi di area Steel Melting Shop adalah kebisingan kontinyu dan merupakan wide band noise. Tentu saja faktor paparan yang seperti ini jika terjadi terus-menerus mengenai para pekerja dapat menimbulkan dampak/efek bagi kesehatan khususnya bagi indera pendengaran para pekerja yang mengakibatkan kenaikan Nilai Ambang Dengar pada pekerja yaitu hasil test audiometri pekerja yang melebihi dari nilai ambang batas.

\section{Karakteristik Pekerja}

Pekerja yang menjadi responden pada penelitian ini adalah berjumlah 28 orang pekerja yang terpapar bising di unit produksi Steel Melting Shop PT. X Sidoarjo. Karakteristik pekerja yang dijabarkan dalam hal ini yaitu terdiri dari umur dan masa kerja dari subjek yang menjadi responden.

Melalui tabel 1 diatas dapat diketahui bahwa sebagian besar usia pekerja yang terpapar bising yang dalam rentang usia 25-30 tahun dan 31-35 tahun masing-masing memiliki jumlah yang sama yaitu terdapat sebanyak 6 responden (21\%) sedangkan untuk pekerja yang rentang usia 36-40 tahun terdapat sebanyak 16 responden (58\%). 
Tabel 1. Distribusi Responden yang Terpapar Bising Menurut Usia pada Pekerja PT. X Sidoarjo Tahun 2015

\begin{tabular}{ccrc}
\hline No. & $\begin{array}{c}\text { Usia Pekerja } \\
\text { (tahun) }\end{array}$ & \multicolumn{2}{c}{ Responden } \\
\cline { 3 - 4 } & $25-30$ & 6 & N \\
\hline 1. & $31-35$ & 6 & 21 \\
2. & $36-40$ & 16 & 21 \\
3. & & 28 & 58 \\
Jumlah & & 100 \\
\hline
\end{tabular}

Sumber: data primer tahun 2015

Tabel 2. Distribusi Responden yang Terpapar Bising Menurut Masa Kerja pada Pekerja PT. X Sidoarjo Tahun 2015

\begin{tabular}{ccc}
\hline \multirow{2}{*}{ Masa Kerja (tahun) } & \multicolumn{2}{c}{ Terpapar } \\
\cline { 2 - 3 } & $\mathbf{N}$ & $\mathbf{\%}$ \\
\hline $5-10$ & 16 & 57 \\
$11-20$ & 12 & 43 \\
\hline Jumlah & 28 & 100 \\
\hline
\end{tabular}

Sumber: data primer tahun 2015

Tabel 3. Distribusi Nilai Ambang Dengar Telinga Kiri Responden yang Terpapar Bising pada Pekerja PT. X Sidoarjo Tahun 2015

\begin{tabular}{crc}
\hline Nilai ambang dengar & \multicolumn{2}{c}{ Responden } \\
\cline { 2 - 3 } & N & $\%$ \\
\hline $15-25 \mathrm{dBA}$ & 9 & 32 \\
$26-35 \mathrm{dBA}$ & 16 & 57 \\
$36-45 \mathrm{dBA}$ & 3 & 11 \\
\hline Jumlah & 28 & 100 \\
\hline
\end{tabular}

Sumber: data sekunder tahun 2015

Melalui tabel 2 di atas menunjukkan bahwa sebagian besar masa kerja pada pekerja yang terpapar bising pada rentang masa kerja 5-10 tahun terdapat sebanyak 16 responden (57\%), sedangkan pekerja yang pada rentang masa kerja 11-20 tahun terdapat sebanyak 12 responden $(43 \%)$.

Melalui tabel 3 diatas dapat diketahui bahwa Nilai Ambang Dengar telinga kiri pekerja yang terpapar bising sebagian besar pada rentang nilai 26-35 dBA yaitu terdapat sebanyak 16 responden (57\%), untuk Nilai Ambang Dengar telinga kiri pekerja yang pada rentang nilai 15-25 dBA yaitu terdapat sebanyak 9 responden (32\%) sedangkan untuk Nilai Ambang Dengar telinga kiri pekerja pada rentang nilai 36-45 dBA yaitu terdapat sebanyak 3 responden (11\%).
Tabel 4. Distribusi Nilai Ambang Dengar Telinga Kanan Responden yang Terpapar Bising pada Pekerja PT.X Sidoarjo Tahun 2015

\begin{tabular}{crr}
\hline \multirow{2}{*}{ Nilai ambang dengar } & \multicolumn{2}{c}{ Terpapar } \\
\cline { 2 - 3 } & N & \% \\
\hline $15-25$ dBA & 11 & 39 \\
$26-35 \mathrm{dBA}$ & 17 & 61 \\
$36-45 \mathrm{dBA}$ & 0 & 0 \\
\hline Jumlah & 28 & 100 \\
\hline
\end{tabular}

Sumber: data sekunder tahun 2015

Tabel 5. Distribusi Status Pendengaran Responden yang Terpapar Bising Pada Pekerja PT.X Sidoarjo Tahun 2015

\begin{tabular}{lrc}
\hline \multirow{2}{*}{ Nilai ambang dengar } & \multicolumn{2}{c}{ Terpapar } \\
\cline { 2 - 3 } & $\mathbf{N}$ & $\mathbf{\%}$ \\
\hline Normal & 6 & 21 \\
Tidak normal & 22 & 79 \\
\hline Jumlah & $\mathbf{2 8}$ & $\mathbf{1 0 0}$
\end{tabular}

Sumber: data sekunder tahun 2015

Melalui Tabel 4 di atas dapat dilihat bahwa Nilai Ambang Dengar telinga kanan pekerja yang terpapar bising lebih banyak yang memiliki nilai ambang dengar pada rentang nilai 26-35 dBA yaitu terdapat sebanyak 17 responden (61\%), untuk Nilai Ambang Dengar telinga kanan pekerja yang pada rentang nilai 15-25 dBA yaitu terdapat sebanyak 11 responden (39\%), sedangkan untuk Nilai Ambang Dengar telinga kanan tidak ada pekerja pada rentang nilai 36-45 dBA.

Tabel 5 di atas menunjukkan bahwa Nilai Ambang Dengar Pekerja yang terpapar bising sebagian besar memiliki Nilai Ambang Dengar yang tidak normal yaitu sebanyak 22 responden (79\%) yang berarti responden banyak yang mengalami penurunan pendengaran sedangkan untuk pekerja yang memiliki Nilai Ambang Dengar yang normal yaitu terdapat sebanyak 6 responden $(21 \%)$.

Tabel 6 menunjukkan bahwa sebagian besar responden yang terpapar bising memiliki status pendengaran telinga kiri normal pada rentang usia 25-30 tahun yaitu terdapat sebanyak 6 responden $(21 \%)$, untuk responden yang memiliki status pendengaran telinga kiri normal pada rentang usia 36-40 tahun yaitu terdapat sebanyak 3 responden $(11 \%)$, sedangkan untuk responden yang memiliki status pendengaran telinga kiri tidak normal sebagian besar pada rentang usia 36-40 tahun yaitu terdapat 
Tabel 6. Distribusi Karakteristik Pekerja Menurut Status Pendengaran Telinga Kiri Pada Pekerja yang Terpapar Bising PT. X Sidoarjo Tahun 2015

\begin{tabular}{lrrrr}
\hline \multicolumn{1}{c}{$\begin{array}{c}\text { Karakteristik } \\
\text { Pekerja }\end{array}$} & \multicolumn{2}{c}{ Normal } & \multicolumn{2}{c}{ Tidak normal } \\
\cline { 2 - 5 } \multicolumn{1}{c}{ N } & \% & N & \% \\
\hline Usia (tahun) & 6 & 21 & 0 & 0 \\
25-30 & 0 & 0 & 6 & 22 \\
$31-35$ & 3 & 11 & 13 & 46 \\
36-40 & 9 & 32 & 19 & 68 \\
Jumlah & & & & \\
Masa kerja (tahun) & 9 & 32 & 7 & 25 \\
5-10 & 0 & 0 & 12 & 43 \\
11-20 & 9 & 32 & 19 & 68 \\
\hline Jumlah & & & &
\end{tabular}

sebanyak 13 responden (68\%), untuk responden yang memiliki status pendengaran telinga kiri tidak normal pada rentang usia 31-35 tahun yaitu terdapat sebanyak 6 responden $(22 \%)$.

Variabel masa kerja pada responden yang terpapar bising yang memiliki status pendengaran telinga kiri normal sebagian besar pada rentang masa kerja 5-10 tahun yaitu terdapat sebanyak 9 responden (32\%). Responden yang memiliki status pendengaran telinga kiri yang tidak normal sebagian besar pada rentang masa kerja 11-20 tahun yaitu terdapat sebanyak 12 responden (43\%) dan untuk responden yang memiliki status pendengaran telinga kiri yang tidak normal pada rentang masa kerja 5-10 tahun yaitu terdapat sebanyak 7 responden $(25 \%)$.

Tabel 7. Distribusi Karakteristik Pekerja Menurut Status Pendengaran Telinga Kanan Pada Pekerja yang Terpapar Bising PT. X Sidoarjo Tahun 2015

\begin{tabular}{lrrrr}
\hline \multicolumn{1}{c}{$\begin{array}{c}\text { Karakteristik } \\
\text { pekerja }\end{array}$} & \multicolumn{2}{c}{ Normal } & \multicolumn{2}{c}{ Tidak normal } \\
\cline { 2 - 5 } \multicolumn{1}{c}{ N } & \% & N & \% \\
\hline Usia (tahun) & 4 & 14 & 2 & 7 \\
$25-30$ & 3 & 11 & 3 & 11 \\
$31-35$ & 5 & 18 & 11 & 39 \\
$36-40$ & 12 & 43 & 16 & 57 \\
Jumlah & & & & \\
Masa kerja (tahun) & 9 & 32 & 7 & 25 \\
5-10 & 3 & 11 & 9 & 32 \\
11-20 & 12 & 43 & 16 & 57 \\
\hline Jumlah & & & & \\
\hline
\end{tabular}

Tabel 7 menunjukkan bahwa sebagian besar responden yang terpapar bising memiliki status pendengaran telinga kanan normal pada rentang usia 36-40 tahun yaitu terdapat sebanyak 5 responden $(18 \%)$, untuk responden yang memiliki status pendengaran telinga kanan normal pada rentang usia 25-30 tahun yaitu terdapat sebanyak 4 responden (14\%), untuk responden yang memiliki status pendengaran telinga kanan normal pada rentang usia 31-35 tahun yaitu terdapat sebanyak 3 responden (11\%), sedangkan untuk responden yang memiliki status pendengaran telinga kanan tidak normal sebagian besar pada rentang usia 36-40 tahun yaitu terdapat sebanyak 11 responden (39\%), untuk responden yang memiliki status pendengaran telinga kanan tidak normal pada rentang usia 31-35 tahun yaitu terdapat sebanyak 3 responden $(11 \%)$, untuk responden yang memiliki status pendengaran telinga kanan tidak normal pada rentang usia $25-30$ tahun yaitu terdapat sebanyak 2 responden (7\%).

Variabel masa kerja pada responden yang terpapar bising yang memiliki status pendengaran telinga kanan normal sebagian besar pada rentang masa kerja 5-10 tahun yaitu terdapat sebanyak 9 responden (32\%), untuk status pendengaran telinga kiri normal pada rentang masa kerja $11-20$ tahun yaitu terdapat sebanyak 3 responden (11\%). Responden yang memiliki status pendengaran telinga kanan yang tidak normal sebagian besar pada rentang masa kerja 11-20 tahun yaitu terdapat sebanyak 9 responden (32\%) dan untuk responden yang memiliki status pendengaran telinga kanan yang tidak normal pada rentang masa kerja 5-10 tahun yaitu terdapat sebanyak 7 responden $(25 \%)$.

Hasil tabel diatas merupakan hasil uji korelasi Pearson dan Spearman pada karakteristik pekerja (usia dan masa kerja) dan Cross-tab pada status paparan terhadap pekerja yang terpapar bising

Tabel 8. Uji Bivariat Karakteristik Pekerja dengan Nilai Ambang Dengar Telinga Kiri Menurut Nilai $p$ pada Pekerja yang Terpapar Bising PT. X Sidoarjo Tahun 2015

\begin{tabular}{lcc}
\hline \multirow{2}{*}{$\begin{array}{c}\text { Karakteristik } \\
\text { pekerja }\end{array}$} & \multicolumn{2}{c}{ Kelompok terpapar } \\
\cline { 2 - 3 } & $\begin{array}{c}\text { nilai } \boldsymbol{p} \text { telinga } \\
\text { kiri }\end{array}$ & $\begin{array}{c}\text { Coefficient } \\
\text { correlation }\end{array}$ \\
\hline Usia & 0,000 & 0,621 \\
Masa kerja & 0,001 & 0,591 \\
Status Paparan & 0,001 & 0,613 \\
\hline
\end{tabular}


Tabel 9. Uji Bivariat Karakteristik Pekerja Ddengan Nilai Ambang Dengar Telinga Kanan Menurut Nilai $p$ pada Pekerja yang Terpapar Bising PT. X Sidoarjo Tahun 2015

\begin{tabular}{lcc}
\hline \multirow{2}{*}{$\begin{array}{c}\text { Karakteristik } \\
\text { pekerja }\end{array}$} & \multicolumn{2}{c}{ Kelompok terpapar } \\
\cline { 2 - 3 } & $\begin{array}{c}\text { nilai } \boldsymbol{p} \text { telinga } \\
\text { kiri }\end{array}$ & $\begin{array}{c}\text { Coefficient } \\
\text { correlation }\end{array}$ \\
\hline Usia & 0,009 & 0,486 \\
Masa kerja & 0,009 & 0,483 \\
Status Paparan & 0,000 & 0,678 \\
\hline
\end{tabular}

dengan Nilai Ambang Dengar telinga kiri responden yang diteliti. Dari hasil tersebut di peroleh $p$-value pada variable usia dengan telinga kiri sebesar 0,000 yang berarti terdapat hubungan atau korelasi antara usia dengan Nilai Ambang Dengar telinga kiri pada pekerja yang terpapar bising.

Variabel usia pada pekerja yang terpapar bising memiliki kuat hubungan, hal ini terlihat dari pearson correlation yang menunjukkan pekerja yang terpapar bising memiliki nilai 0,621 yang mendekati angka 1 .

Variabel masa kerja pada pekerja yang terpapar bising diperoleh nilai $p<\alpha$ yang berarti terdapat hubungan antara masa kerja dengan Nilai Ambang Dengar telinga kiri dan dilihat dari tingkat kemaknaannya pekerja yang terpapar bising memilih kuat hubungan dengan Nilai Ambang Dengar yaitu dilihat dari nilai pearson correlation yang menunjukkan pekerja yang terpapar bising memiliki nilai 0,591 yang mendekati angka 1 .

Hasil tabel uji bivariat diatas di peroleh $p$-value pada variabel usia dengan telinga kanan pada pekerja yang terpapar bising sebesar 0,009 yang berarti terdapat hubungan atau korelasi antara usia dengan Nilai Ambang Dengar telinga kanan pada pekerja yang terpapar bising. Variabel usia pada pekerja yang terpapar bising memiliki kuat hubungan, hal ini terlihat dari pearson correlation yang menunjukkan nilainya mendekati angka 1 yaitu sebesar 0,486 .

Variabel masa kerja, pada pekerja yang terpapar bising diperoleh nilai $\mathrm{p}<\alpha$ yang berarti terdapat hubungan antara masa kerja dengan Nilai Ambang Dengar telinga kanan dan dilihat dari tingkat kemaknaannya pekerja yang terpapar bising memilih kuat hubungan dengan Nilai Ambang Dengar yaitu dilihat dari nilai pearson correlation yang menunjukkan pekerja yang terpapar bising memiliki nilai 0,483 yang mendekati angka 1 .

\section{PEMBAHASAN}

\section{Hasil Pengukuran Intensitas Kebisingan}

Berdasarkan hasil pengukuran intensitas kebisingan di unit produksi Steel Melting Shop didapatkan hasil rata-rata kebisingan di unit produksi Steel Melting Shop PT. X Sidoarjo sebesar 106 dB. Berdasarkan hasil pengukuran tersebut menurut PermenakerTrans No. 13/Men/X/2011 tentang Nilai Ambang Batas Faktor Fisika dan Faktor Kimia di Tempat Kerja yang menyatakan bahwa pekerja tidak boleh terpapar lebih dari $85 \mathrm{~dB}$ selama lebih dari 8 jam per hari atau 40 jam per minggu. Paparan sebesar $106 \mathrm{~dB}$ hanya diperbolehkan maksimal 3, 75 menit dalam sehari. Pada kenyataan yang ada para pekerja yang terpapar bising mengalami paparan 106 dB lebih dari 3, 75 menit dalam sehari.

Jenis kebisingan di tempat kerja adalah wide band noise atau kebisingan yang menetap yang berkelanjutan tanpa putus-putus dengan frekuensi lebar dan tinggi. Secara teori, kebisingan dengan nada sempit dan tinggi lebih cepat dan efektif menimbulkan ketulian. Menurut Harrianto (2008), tuli dapat disebabkan oleh tempat kerja yang terlalu bising

Keadaan area kerja yang bising ini disebabkan oleh suara-suara mesin peleburan, pemurnian dan pencetakan baja yang merupakan satu kesatuan dalam sebuah produksi baja dan mesin tersebut tidak pernah berhenti berbunyi jika tidak dalam maintenance. Disinilah terjadinya pada pekerja yang terpapar bising di unit produksi Steel Melting Shop PT.X Sidoarjo mengalami paparan bising secara langsung.

Menurut Tjan dkk (2013), mengatakan bahwa terdapat hubungan yang bermakna antara gangguan pendengaran dengan intensitas kebisingan sedangkan Amalia dkk (2012), mengatakan bahwa terdapat pengaruh antara intensitas bising terhadap derajat gangguan pendengaran dan juga terdapat pengaruh antara lama tinggal terhadap derajat gangguan pendengaran.

Suara bising adalah suatu hal yang dihindari oleh siapa pun, lebih-lebih dalam melaksanakan suatu pekerjaan, karena konsentrasi pekerja akan dapat terganggu sehingga maka pekerjaan yang dilakukan akan banyak timbul kesalahan ataupun kerusakan sehingga akan menimbulkan kerugian (Anizar, 2012).

Kebisingan juga dapat memberikan efek kesehatan selain pendengaran pada beberapa bagian tubuh secara visceral seperti perubahan frekuensi 
jantung, perubahan tekanan darah dan tingkat pengeluaran keringat (Harrington, 2003).

\section{Hubungan Usia dengan Nilai Ambang Dengar}

Usia merupakan faktor penentu terjadinya kenaikan Nilai Ambang Dengar seseorang. Semakin bertambah usia seseorang, maka akan semakin menurun Nilai Ambang Dengar (Tambunan, 2005).

Pekerja yang terpapar bising sebagian besar respondennya adalah yang memiliki rentang usia 3540 tahun. Di mana kategori usia tersebut merupakan kategori usia yang paling tua.

Variabel umur dalam penelitian ini dibatasi sampai usia 40 tahun, menurut teori dari Soepardi (2007), yang mengatakan bahwa dengan bertambahnya usia seseorang maka akan terjadi penurunan fungsi pendengaran secara progresif dan bertahap. Secara normal usia lebih dari 40 tahun akan mengalami penurunan kemampuan pendengaran.

Hasil uji bivariat menggunakan uji korelasi diperoleh $\mathrm{p}<\alpha$ untuk kedua hubungan yaitu hubungan usia dengan Nilai Ambang Dengar telinga kiri dan Nilai Ambang Dengar telinga kanan hal ini menunjukkan bahwa usia memang berhubungan dengan terjadinya ketulian.

Menurut Achmadi (2013), bahwa usia merupakan faktor yang tidak secara langsung memengaruhi keluhan subjektif gangguan pendengaran akibat kebisingan namun pada usia di atas 40 tahun akan lebih mudah mengalami gangguan pendengaran dan rentan terhadap trauma akibat bising. Penurunan daya dengar secara alamiah yang diasumsikan mengakibatkan peningkatan ambang pendengaran $0,5 \mathrm{~dB}(\mathrm{~A})$ tiap tahun sejak usia 40 tahun.

Adanya hubungan yang signifikan antara pertambahan usia dengan peningkatan Nilai Ambang Dengar pada responden membuktikan bahwa presbikusis merupakan faktor yang dapat memengaruhi nilai ambang dengar responden selain intensitas paparan, lama waktu paparan dan kepekaan individu tersebut. Presbikusis adalah tuli sensorineural atau penurunan pendengaran yang diakibatkan oleh peningkatan usia, pada test audiometri, presbikusis tidak berpengaruh pada frekuensi $4000 \mathrm{~Hz}$ melainkan pada frekuensi yang lebih tinggi.

\section{Hubungan Masa Kerja dengan Nilai Ambang Dengar}

Menurut Tarwaka (2014), faktor yang paling mempengaruhi nilai ambang dengar adalah faktor umur dan lamanya pemajanan terhadap kebisingan. Seseorang pekerja memiliki masa kerja lebih lama mungkin lebih berisiko mengalami penyakit akibat kerja dibandingkan pekerja yang memiliki masa kerja yang lebih pendek. Hasil analisis mengenai masa kerja terhadap Nilai Ambang Dengar pekerja dapat dilihat melalui tabel 6 dan 7, dari tabel tersebut dapat diketahui bahwa sebagian besar pekerja yang terpapar bising memiliki masa kerja 5-10 tahun Nilai Ambang Dengar nya normal sedangkan pada rentang masa kerja 11-20 tahun sebagian besar Nilai Ambang Dengar nya tidak normal.

Penelitian ini untuk variabel masa kerja dibatasi minimal pekerja sudah 5 tahun bekerja di tempat bising, hal ini dikarenakan paparan kebisingan $>$ $85 \mathrm{~dB}$ (A) ada kemungkinan setelah 5 tahun kerja, $1 \%$ pekerja akan memperlihatkan sedikit gangguan pendengaran. Ketulian bersifat progresif atau awalnya bersifat sementara tetapi bila bekerja terusmenerus di tempat bising tersebut maka daya dengar menghilang secara menetap atau tuli (Buchari, 2007).

Hasil uji korelasi pearson dari kedua Nilai Ambang Dengar yaitu memiliki $p$-value 0,036 atau $\mathrm{p}<\alpha$ yang berarti terdapat hubungan antara masa kerja dengan Nilai Ambang Dengar pekerja. Adanya hubungan masa kerja dengan penurunan Nilai Ambang Dengar pada pekerja yang terpapar bising dikarenakan pada area kerja terdapat intensitas kebisingan yang tinggi dan mempengaruhi Nilai Ambang Dengar pekerja sehingga mengalami ketulian. Hal ini terjadi karena terus-menerus paparan bising diterima oleh pekerja.

Menurut Tarwaka (2014), mengatakan bahwa faktor masa kerja berpengaruh terhadap nilai ambang dengar tenaga kerja. Kenaikan ambang dengar pada kelompok masa kerja $>10$ tahun juga lebih tinggi dari kelompok masa kerja 6-10 tahun dan 1-5 tahun.

\section{Nilai Ambang Dengar Pekerja}

Berdasarkan hasil penelitian ternyata $79 \%$ para pekerja yang terpapar bising mengalami kenaikan Nilai Ambang Dengar akibat adanya paparan bising 
dengan intensitas tinggi di tempat kerja. Nilai Ambang Dengar pekerja dapat dilihat melalui tabel 5 di mana pada pekerja yang terpapar bising dari 28 sampel pekerja hanya 6 responden (21\%) yang tidak mengalami ketulian dan sisanya sebanyak 22 responden $(79 \%)$ mengalami ketulian.

Penelitian yang dilakukan oleh Hidayati (2012), menunjukkan bahwa kebisingan yang diterima karyawan adalah ada hubungan antara intensitas kebisingan dengan nilai ambang dengar pada telinga kiri dan kanan.

Menurut Ida (2008), menyatakan bahwa seseorang yang berada diatas nilai ambang bising secara terus-menerus dapat mengakibatkan terjadinya penurunan pendengaran.

Gangguan yang disebabkan oleh kebisingan yang mengakibatkan kenaikan Nilai Ambanhg Dengar yang tidak dicegah maupun diatasi bisa menimbulkan kecelakaan, baik pada pekerja maupun orang di sekitarnya (Chaeran, 2008).

\section{Hubungan Kebisingan dengan Nilai Ambang Dengar}

Berdasarkan Tabel 8 dan 9 diketahui seluruh nilai $p$-value dan kuat hubungan, bahwa karakteristik pekerja (usia dan masa kerja) dan status paparan pada pekerja yang terpapar bising diatas terdapat hubungan.

Hasil tabel uji bivariat 8 dan 9 keduanya menunjukkan bahwa terdapat hubungan atau korelasi antara kebisingan dengan Nilai Ambang Dengar dengan koefisien sebesar 0,613 untuk telinga kiri dan sebesar 0,678 untuk telinga kanan. Ini menunjukkan hubungan paparan kebisingan dengan Nilai Ambang Dengar memiliki koefisien mendekati angka 1 yang berarti memiliki hubungan cukup kuat.

Soeripto (2008), menyatakan bahwa ketulian atau peningkatan ambang pendengaran akibat paparan kebisingan diawali dengan adanya peningkatan ambang pendengaran pada frekuensi $4000 \mathrm{~Hz}$.

Intensitas kebisingan yang tinggi dapat mempengaruhi daya dengar seseorang yang terpapar oleh kebisingan tersebut dan semakin lama akan semakin menyebabkan ketulian Achmadi (2013), sehingga dapat disimpulkan bahwa terjadinya kenaikan Nilai Ambang Dengar pada pekerja yang terpapar bising memang disebabkan oleh kebisingan yang ada di area kerja.

Menurut Soeripto (2008), akibat pemajanan terhadap bising dengan intensitas tinggi maka akan menyebabkan gangguan penurunan daya dengar yang sifatnya sementara dan apabila diberi istirahat yang cukup maka akan kembali normal seperti semula.

Menurut Setyanto dkk (2011), dalam penelitiannya menyatakan bahwa faktor tingkat kebisingan memberikan pengaruh yang sangat besar terhadap waktu penyelesaian pekerjaan. Paparan kebisingan yang tinggi dapat mempengaruhi nilai ambang dengar seseorang. Nilai ambang dengar dalam hal ini adalah bunyi terlemah yang masih dapat didengar telinga (Tambunan, 2005).

Yavie dkk (2014), mengatakan dalam penelitiannya bahwa ada hubungan yang signifikan antara gangguan pendengaran dengan usia, masa kerja, penggunaan obat ototoksik, merokok dan kebisingan sedangkan

Menurut Haurisa dkk (2013), dalam penelitiannya mengatakan bahwa siswa dengan paparan bising 100-105 dB, terdapat pengaruh paparan bising terhadap ambang pendengaran.

Efek yang ditimbulkan kebisingan Chaeran (2008), diantaranya yaitu efek psikologis pada manusia kebisingan dapat membuat kaget, mengganggu dan mengacaukan konsentrasi, menginterferensi komunikasi dalam percakapan dan akan menginterferensi hasil pekerjaan dan keselamatan kerja dan efek fisis kebisingan dapat mengakibatkan penurunan kemampuan pendengaran dan rasa sakit pada tingkat yang sangat tinggi

\section{SIMPULAN}

Hasil pengukuran audiometri terhadap 28 sampel dari pekerja yang terpapar bising, 22 orang memiliki Nilai Ambang Dengar tidak normal $(>25$ dB) dan 6 orang memiliki Nilai Ambang Dengar normal $(\leq 25 \mathrm{~dB})$.

Adanya hubungan usia dan masa kerja dengan Nilai Ambang Dengar pada pekerja yang terpapar bising. Lakukan rotasi pekerja untuk mengurangi lama paparan pada pekerja yang berisiko tinggi terpapar bising.

\section{DAFTAR PUSTAKA}

Achmadi. 2013. Upaya Kesehatan Kerja Sektor Informal di Indonesia. Jakarta: Depkes RI.

Amalia, L. Lanjahi, G. 2012. Pengaruh Intensitas Kebisingan dan Lama Tinggal terhadap Derajat Gangguan Pendengaran Masyarakat Sekitar Kawasan Pltd Telaga Kota Gorontalo. Jurnal Saintek, Vol. 7 No. 3. 
Anizar. 2012. Teknik Keselamatan dan Kesehatan Kerja di Industri. Yogyakarta: Graha Ilmu.

Buchari. 2007. Kebisingan Industri dan Hearing Conservation Program. Universitas Sumatra Utara. Medan: Badan Penerbit USU.

Chaeran, M. 2008. Studi Kasus Bandara Ahmad Yani Semarang. Tesis. Semarang: Universitas Diponegoro.

Chandra, B. 2007. Pengantar Kesehatan Lingkungan. Jakarta: EGC.

Harrianto, R. 2010. Buku Ajar Kesehatan Kerja. Jakarta: Penerbit buku Kedokteran EGC.

Haurissa, M.P., Mengko, S.K., Palendeng, O.I. Pengaruh paparan bising terhadap ambang pendengaran siswa SMK Negeri 2 Manado jurusan teknik konstruksi batu beton. Jurnal e-Clinic (eCl), Vol. 2 No. 1.

Harrington, J.M. 2003. Buku Saku Kesehatan Kerja. Dublin, Ohio: Penerbit Buku Kedokteran, EGC

Hidayati, S. U. 2012. Pengaruh masa kerja, intensitas kebisingAn dan rutinitas pemakaian Alat pelindung telinga dengan ambang pendengaran karyawan di Bagian Roughmill PT MaitlandSmith Indonesia Semarang. Skripsi. Semarang: Universitas Diponegoro.

Ida, Y. 2008. Kebisingan, Pencahayaan dan Getaran di Tempat Kerja. Bandung: Mitra.

Internasional Labour Organisation (ILO). 2012. Data Kecelakaan Kerja. Jakarta.

Kementerian Tenaga Kerja dan Transmigrasi. 2010. Data kecelakaan Kerja. Jakarta.

Notoatmodjo, S. 2007. Ilmu Kesehatan Masyarakat, Prinsip-prinsip Dasar. Jakarta: Rineka Cipta.

Notoatmodjo, S. 2010. Metodologi Penelitian Kesehatan. Jakarta: Rineka Cipta.

PermenakerTrans No.13/MEN/X/2011. Tentang "NAB Faktor Kimia dan Fisika di Tempat Kerja". Jakarta: Depnaker.

Prabu, P. 2009. Dampak Kebisingan terhadap Kesehatan. http://putraprabu.wordpress.com. Diakses pada 28 Maret 2015.
Putri, W.W. 2016. Pengaruh Intensitas Kebisingan dan Karakteristik Pekerja terhadap Penurunan Pendengaran Pekerja yang Terpapar Bising. Skripsi. Surabaya: Universitas Airlangga.

Siregar, M.P. Hubungan Kebisingan dengan Kemampuan Pendengaran Tenaga Kerja Bagian Pengolahan Kelapa Sawit Adolina PTPN IV Kabupaten Serdang Bedagai. Skripsi. Medan: Universitas Sumatera Utara.

Soemirat, J.2011. Kesehatan Lingkungan. Yogyakarta: Gadjah Mada University Press.

Soeripto. 2008. Higiene Industri. Jakarta: Balai Penerbit FKUI.

Suma'mur. 2009. Higiene Perusahaan dan Keselamatan Kerja (HIPERKES). Jakarta: Sagung Seto.

Soepardi. 2007. Telinga, Hidung, Tenggorok, Kepala \& Leher. Edisi ke 6. Jakarta: Balai Penerbit FK UI.

Setyanto, H. R. Subiyanto, A. A. Wiryanto. 2011. Pengaruh Faktor Lingkungan Fisik Kerja terhadap Waktu Penyelesaian Pekerjaan (Studi Laboratorium). Jurnal Ekosains, Vol. 3. No. 2.

Tambunan, Sihar Tigor Benjamin. 2005. Kebisingan di Tempat Kerja (Occupational Noise). Yogyakarta: ANDI.

Tarwaka. 2014. Keselamatan dan Kesehatan Kerja; Manajemen dan Implementasi K3 di Tempat Kerja. Surakarta: Harapan Pres.

Tjan, H., Lintong, F., Supit, W. 2013. Efek Bising Mesin Elektronika terhadap Gangguan Fungsi Pendengaran pada Pekerja di kecamatan Sario Kota Manado Sulawesi Utara. Jurnal Biomedik (eBM), Vol. 1. No. 1.

Yavie, M.A., Ma'rufi, I., Sujoso, A.D.P. 2014. Hubungan Antara Intensitas Kebesingan dengan Gangguan Pendengaran pada Pekerja Mebel Informal di Kelurahan Bukir Kecamatan Gadingrejo Kota Pasuruan. Jurnal Pustaka Kesehatan, Vol. Oktober 2014. 